\title{
THE CONCEPT OF AGE IN THE ENGLISH-SPEAKING CULTURE
}

\author{
Osova O. O., Panchenko V. V.
}

\section{INTRODUCTION}

Interest in languages, how they originated, how they work and develop, has existed from time immemorial. At the present stage of the development of the linguistics the key role belongs to the anthropocentric paradigm, which presents the language as a system forming the constitutive features of a personality. The fundamental characteristics of the language system are developed under the influence of the general biological and neurophysiologic constitution of man and are closely connected with his thinking process, spiritual and practical activity, personality, knowledge about the world. That is why the attention of modern linguists is concentrated on the cognitive, cultural and sociologic aspects of the language, which are the objects of study of such sciences as cognitive linguistics, sociolinguistics, linguistic and cultural studies. The notion which unites linguistic, cultural and cognitive phenomena is the concept as the sense category with value, image and notion constituents.

Taking into consideration language anthropocentricity and the leading role of cognitive and cultural researches in modern linguistics we've decided to analyze concept AGE. The choice of this concept is caused by the multidimensional character of age phenomenon and by the absence of profound analysis of the means of its verbalization in the English language.

In view of all aforesaid our aim is to show the specificity of the concept of age perception and verbalization on the material of the English phraseological and lexical units.

To attain the aim of the research the following methods were used: the method of total sampling, structural, semantic and cognitive analysis, field modeling method. With the help of the method of total sampling the units under analysis were selected from the dictionaries, specificity of concept AGE verbalization means in Modern English was defined with the help of structural, semantic and cognitive analysis, field modeling method was used to build up the lexico-semantic field of concept AGE realization.

Theoretical grounds of our research are the works by V. Karasyk, I. Sternyn, Z. Popova, A. Rudakova, Ju. Stepanov and the others devoted to the history and methods of cognitive linguistics, linguistic and cultural studies, concept structure and formation. Lexical and phraseological nominations of age were selected from the English-Russian Dictionaries of 
Idioms by A. Koonin and Ju. Barantsev and Longman Dictionary of Contemporary English.

\section{The concept of age as a culturally relevant phenomenon}

Tendency to the diffusion of the various branches of scientific knowledge is one of determining characteristics of science in $\mathrm{XX}$ XXI centuries. In the field of humanities this aspiration to synthesis was expressed through researches of culture phenomena, including all varieties of human activities and their results. Key idea in modern linguistics is the idea of language anthropocentricity. In the center of everything described by words there is an individual and everything that is perceived as their surroundings, sphere of their existence. From the point of view of anthropocentric paradigm a person cognizes the world through growing selfawareness, through theoretical and practical activities. This paradigm is based on switching the focus of researchers' interests from the objects of cognition to the subject, i.e. a man in a language and a language in a man are analyzed. From the moment of birth a person cognizes their environment, learns to recognize objects, to correlate them with each other, to generalize, learns to process and memorize information, to express the results of the cognition using the language. As a result common notions are formed which later will be united in the system of knowledge about the world. This sy stem consists of concepts of a different level of complexity and abstraction formed in different ways ${ }^{1}$.

A concept appears as an image, but once formed in the consciousness, this image is able to move up according to the degree of abstraction. The primary concept content becomes more complicated due to the knowledge received as a result of other types of cognitive activities, i.e. some cogitative content, logical associations are added. With the increase of level of abstraction the concept gradually transforms from a perceptible image into a cogitative one. At the same time the well-known fact that any concept should be explained by an example, proves the concept imaginative nature.

For a child, whose concept sphere is still in the process of formation, a concept is usually equal to a concrete perceptible image (for a child Jerry, dog, collie and animal is one object, all these words represent one perceptible concept in his consciousness - picture of his own dog). Later each of the lexemes mentioned above will present different, though hieratically connected concepts (animal - dog - collie - Jerry). For an

Болдырев Н.Н. Когнитивная семантика: Курс лекций по английской филологии. Тамбов : ТГУ, 2001. С. 21 
intelligent uncultivated person concepts are hardly different from the initial empiric images ${ }^{2}$.

Thus, a primary empiric image at first functions as concrete perceptible concept content, and then becomes a means of encoding, a sign of a multidimensional concept which is becoming more and more complicated in the process of its comprehension ${ }^{3}$.

Since the concept is a unit of culture, it must include the value constituent and its presence distinguishes the concept from other mental units. The concept turns to be that structure of consciousness, in which the values of society are fixed. Besides the value constituent, notional and imaginative elements are also included into the structure of the concept. A notional element is formed by actual information about a real or imaginary object. The imaginative constituent of the concept is related to the method of cognition of reality. In this element all naive presentations fixed in the language are included; internal forms of the words which serve to express the concept.

One of the basic questions of concept studies is a question about correlation of concepts and language units. The fact that a word and a concept have the common plane of expression creates a peculiar scientific intrigue, which allows for a paradoxical as sertion: the concept is both a word and a non-word. Description of some word-concepts of folk culture can be related to concepts of the same culture. Describing the relation of the explored word to another word, we get partial interpretation of the word we are interested in. A. Wierzbitcka thinks that terms "word" and "concept" are interchangeable. She introduces such notions as "concept-minimum, which is incomplete domain by word meaning, inherent to the ordinary transmitter of language" and "concept-maximum, which is complete domain by word meaning" 4 .

In the process of communication the concept is expressed mainly by language signs. There is a linguistic unit (word, word combination, idiom, sentence etc), expressing the concept in the most complete and general form. This unit is used as the concept name by the researchers. However, the concept name is not the only sign, which can activate it in human consciousness. Any concept is characterized by its ability to be realized in different forms. "The more varied language means of the concept expression, the more ancient and the more important for this language

2 Попова 3.Д., Стернин И.А. Очерки по когнитивной лингвистике. Воронеж : Истоки, 2001. С. 43.

3 Болдырев Н.Н. Когнитивная семантика: Курс лекций по английской филологии. Тамбов : ТГУ, 2001. С. 30.

4 Вежбицкая А. Язык. Культура. Познание. Москва : Русские словари, 1997. C. 304 . 
society this concept is" ${ }^{~}$. In the period of its existence a concept can lose connection with some linguistic units and attract new ones.

Concept AGE has existed in human languages since the very beginning. Ever since Oedipus solved the riddle of the sphinx, thereby winning the prizes of kingship, incest, guilt and blindness, writers and thinkers have been trying to outdo his analytical feat. While he knew that what walked on four legs in the morning, two in the afternoon, and tree in the evening was man in his three ages, we prefer to think of man's ages as seven in number, taking out cue from Shakespeare. First comes "the infant, mewling and puking", then "the whining schoolboy", then "the lover, sighing like a furnace", followed by the soldier, full of strange oaths". Hard upon his heels strolls the stately "justice $<\ldots>$ full of wise saws". The sixth age is that of an old man who waits "the last scene of all", a senile second childhood in which he is «sans teeth, sans eyes, sans taste, sans everything" ${ }^{\circ}$. Surely no mortal lives who has not wanted to escape from the painful reality of all these stages, especially the unmentioned stage, death.

When we attempt to describe someone else, or when we are required to describe ourselves (for example, on an official form) age almost always seems to be a crucial component to such descriptions. Age shapes and sets limits upon the way we live our lives in a way that we very much take as granted. As the timeline shows, age dictates such things as when we can leave school, when we can drive, when we can marry, when we can join the army, when we can drink alcohol, we can retire, and of course when we can vote. In an obvious sense, age is a fact we cannot alter because it literally describes how long we have been alive. It is something which fixes our position in society as much as, and often more than, other factors such as race, gender or class. Nevertheless, once we begin to consider the different ways in which age underpins the identity of any given individual, it emerges as a category that is far from being simply a biological given. The social effects of age have implications far beyond the explicit classification of a person's physical, chronological status. Age, consequently, is an aspect of identity which powerfully reflects the particular character of life in any national culture and we can learn a lot about a nation's meanings and cultural practices by paying attention to the significance it attaches to certain life stages. In other words, age is a component of identity which is very

${ }^{5}$ Слышкин Г.Г. От текста к символу. Лингвистические концепты прецедентных текстов в слушании или дискурсе. Москва : Academia, 2000. С. 56.

${ }^{6}$ Shakespeare W. The Seven Ages of Man («All the World's a Stage»). URL: https://genius.com/William-shakespeare-the-seven-ages-of-man-all-the-worlds-a-stageannotated 
much tied to cultural factors such as the education system, health or marriage practices.

\section{Lexico-semantic analysis of concept AGE verbalization means}

According to our data selected from the English-Russian Dictionaries of Idioms by A. Koonin and Ju. Barantsev and Longman Dictionary of Contemporary English concept AGE is represented in the English language by 88 phraseological units and 189 lexical units. They can be classified according to the following criteria:

- period of life, which is marked by the lexeme (childhood, youth, middle age, old age);

- gender reference;

- way in which age is named (explicitly or implicitly);

- evaluative connotation of the lexeme;

- national-cultural components in the meaning of the lexeme;

- stylistic connotation;

- features of character typical for a particular age.

A person's life consists of 4 four important stages, four steps in the process of aging: childhood, youth, middle age and old age. This is reflected in the language.

In our sample $52(18.8 \%$ ) lexemes mark childhood (for instance, the olive branch - children, little beggars - little children, teenybopper - a girl between the ages of about 9 and 14, who is very interested in popular music, teenage fashion etc, Goldilocks - a humorous name for a little girl with blonde hair, kiddie - a young child, ragamuffin - a dirty young child wearing torn clothes, toddler - a very young child who is just learning to walk), 73 (26.4\%) - youth (for example, one's salad days - young years, period of inexperienced youth, sweet seventeen - happy girlish years, tender age - young, early age, Adonis - an extremely attractive young man, the rising generation - young people who will soon be enough to vote, have jobs etc, whippersnapper - a young person who is too confident and does not show enough respect to older people, the first flush of youth/manhood-the beginning of a period of time when you are young, a (proper) little madama young girl who is very confident and expects other people to everything she wants), $15(5.4 \%)$ - middle age (examples are as follows: a new lease life - the second youth, on the shady (wrong) side of thirty (forty, etc) older than 30 (40 etc.), be no chicken - used to say that someone is no longer young - used humorously, be pushing 40/60 - to be nearly 40, 60 etc years old, mature - a polite or humorous way of describing someone who is no longer young, matronly - used to describe a woman who is fairly fat and no longer young - to avoid saying this directly), 87 (31.5\%) - old age (for 
instance, old hooker - old person, old duck - grandmother, the afternoon of life - in one's old age, centenarian-someone who is 100 years old or older, second childhood - someone who is in their second childhood is old, and their mental abilities are greatly reduced, sage - an old man who is very wise).

Some PU (phraseological units), such as to carry one's years well, to bear one's age well - don't look one's age, to look young for one's age, can be use in relation to people in both middle and declining years.

When we want to say how old a person is we can use the following expressions: be 5/10/35 etc, be 5/10/35 etc years old, be 5/10/35 years of age, aged $5 / 10 / 35$ etc, of 5/10/35 etc, in your teens/20s/thirties/40s etc, have turned 20/30 etc.

Also we can single out phrases that do not name age directly but just indicate the process of aging, e.g. coming of age, grow old, ageing, show yourage.

A separate group of lexemes referring to the people of the same age can be distinguished: age group, age bracket, age range - the people between two particular ages, considered as a group, peer group - a group of people, especially people who are the same age, social class etc as yourself.

To concept AGE verbalization means also belong 9 lexemes (3.3\%) indicating the relations of seniority between people. Here we have big sister/brother-your older sister/brother, elder-the elder of two people, be somebody's elder, be two/ten years somebody's elder - to be older than someone else, be two/fivelten etc years somebody's senior - to be two, five, ten etc years older than someone, be two/five/ten etc years somebody's junior, be somebody's junior by two/five/ten etc years - to be twolfive/ten etc years younger than someone.

Since age is a complex biological, psychological, sociological category and nobody knows for sure when a person crosses the border between childhood and youth, youth and middle age, middle age and advanced years, there are a lot of expressions that reflect this phenomenon. For instance, colleen - a girl or a young woman, juvenile delinquent - a child or young person who behaves in a criminal way, maiden - a young girl or a woman who is not married, youngster - a child or young person, childbearing agelyears - if a woman is of childbearing age or in her childbearing years, she is of an age when it is physically possible for her to have babies (the last can be used for either a young or a middle-aged woman).

The next aspect of our classification is the reference of lexical units. We can single out:

- lexemes that mark women's age;

- lexemes that mark men's age;

- lexemes that name age regardless of gender. 
According to our data the nomination of women's age is characteristic for $52(18.7 \%)$ lexemes (examples: sweet seventeen - happy girlish years, old duck - grandmother, mutton dressed as a lamb - elderly woman who tries to look young, crone - an ugly or unpleasant old woman, matriarch an older woman, who controls a family or a social group, flapper - a fashionable young woman in the late 1920s, nubile - a woman who is nubile is young and sexually attractive), 27 (9.7\%) lexemes refer to masculine gender (a young shaver - young man, old broke - an old unpleasant man, Billy Bunter-gluttonous, thick, blundering teenager, as old as Methuselahvery old, Adonis - an extremely attractive young man, father figure - an older man who you trust and respect, gaffer - an old man, sage - an old man who is very wise, lad - a boy or a young man), 197 (70.6\%) units indicate age, regardless of gender (one's early days - youth, in the flower oflife - in the bloom of life, getting on in years - not in the first youth, geriatric - too old to work well, octogenarian - someone who is between 80 and 89 years old, pre-school - relate to the time in a child's life before they are old enough to go to school, teenage - aged between 13 and 19, knee-high to a grasshopper-used when talking about the past to say that someone was a young child then).

The fact that the majority of units under analysis can be used in reference to both males and females is another evidence of the universal character of concept AGE.

All the selected units from the semantic field 'age' can be divided into two classes according to the way of age nomination:

- those that name a person's age explicitly (directly), giving exact figures or stating that the given figure is approximate;

- those that name age implicitly, without mentioning any figures but using metaphoric, metonymic, euphemistic words and phrases, allusions etc.

We conducted calculations and found out that in 104 (38.4\%) lexemes from our selection the nomination of age is explicit and in $167(61.6 \%)-$ implicit. For instance: explicitly: on shady (wrong) side thirty (forty, etc) older than 30 (40 etc.) years; on right (sunny) side thirty (forty, etc) younger than 30 (40 and etc) years, under 30 (40 and etc) years; silver jubilee - 25-years-old jubilee, be pushing 40/60 etc - to be nearly 40, 60 etc years old, twentysomething - someone who is between the ages of 20 and 29, 5/10/50 years old - used to talk about how long a person has lived; implicitly: decline into vale years - to become old; to win one's latchkey-to become adult and get the key from an entrance door (to come back home when pleasing); a bread and butter miss - pupil, girl of school age, teenybopper - a girl between the ages of about 9 and 14, who is very interested in popular music, teenage fashion etc, groupie - a young woman who follows popular musicians or other famous people around, hoping to 
meet them, Jack the Lad - a young man who enjoys drinking alcohol and going out with his male friends, and who thinks he is sexually attractive.

The prevalence of implicit nominations may be accounted for by the well-spread phenomenon of euphemism (or dysphemism), especially in reference to old people, and abundance of poetic and jocular metaphoric and metonymic nominations used in literature and informal communication.

Negative or positive connotation of expressions is usually connected with negative or positive images that are incarnated in a certain phrase and based on literal meanings of their components.

For example, in PU a green old age - happy cheerful old age positive evaluation is indicated by the component 'green', which is associated with images of spring, bloom, and in combination with the element 'old age' means that an elderly person despite old age feels well and energetic. Positive connotation of such PU, as silver jubilee - 25-years-old jubilee, golden jubilee - a 50-annual jubilee, diamond jubilee - a 60-, 70-annual jubilee is explained by the presence of components 'silver', 'golden', 'diamond' that name noble metals. All the expressions with the components 'well', 'new', 'flush', 'bloom', 'flower' are positive (to carry one's years well, to bear one's age well-don't look one's age, to look young for one's age, the first flush of youth/manhood - the beginning of a period of time when you are young, in the bloom of youth, in the flower of life - to be young and active, a new lease of life - the second youth). When describing an old person with the help of such words as 'sprightly' or 'spry' we presuppose energy, activeness, good spirits.

On the contrary, some PU belong to the group with negative evaluative connotation: mutton dressed as a lamb-elderly woman who tries to look young, old broke-old unpleasant man. In the first case negative connotation is created by metaphorical adversative comparison of an elderly woman aspiring to look like a young girl (lamb) with a sheep. In the second case the element 'broke', that by itself is associated with destruction, indicates an elderly man with repellent appearance and bad character. Negative connotation is also observed in a number of lexemes describing unpleasant, annoying or nasty old persons. For example, an ugly or unpleasant woman can be referred to as 'hag' or 'witch'. Both words have their roots in old superstitions and beliefs about women endowed with supernatural forces and abilities, 'dark magic' always causing damage to ordinary people. Another name for an annoying old woman is 'old trout'. Negative evaluation is clearly understood by drawing a parallel to a not fresh fish, which has a disgusting smell and taste. Talking about young people the negative effect is achieved through the composition of words and word combinations. For example, ladette - a young woman who likes to do some things that young men typically do, such as drinking a lot of alcohol and talking about sex. It 
is formed from the root "lad", meaning a boy or young man and feminine suffix -ette. Negative evaluation is based on gender stereotypes. In the word combination 'lager lout' - a young man who drinks too much and behaves violently or rudely - negative connotation is indicated by the combination of the component 'lager' - a light-coloured beer (alcoholic drink) and emotionally coloured component 'lout' - a vulgar young man with rude manners. One more example can be provided: a young person who behaves badly and often gets into trouble is called a 'tearaway'. The combination of the noun 'tear' and the preposition 'away' proves this lexeme's negative connotation.

In the semantic group that serves for the verbalization of concept AGE $50(18.5 \%)$ units have negative estimation, $34(12.5 \%)$ - positive and $187(69 \%)$ - neutral.

The following lexemes can be supplied as examples of neutral: age of consent - the age when someone can legally get married or have a sexual relationship, childhood - the period of life when you are a child, retire someone who has stopped working, usually because of their age, septuagenarian - someone who is between 70 and 79 years old, kid - a young person, underage - too young to legally buy alcohol, drive a car, vote etc., girl - a female child or young woman.

Predominance of neutral lexemes, which are as a rule frequently used, proves the importance of concept AGE for English culture. It is obvious that there must be a number of neutral age nominations in any language since age is a necessary component to be mentioned while filling in official forms and documents, while describing a person etc. Age is viewed as something that makes up a part of human existence, a characteristic of it. Negative expressions belong mostly to the semantic subgroup "old age". It is connected with the general perception of old age as an end of life, the time of illnesses, loneliness, sadness and the phenomenon of "ageism" in the English culture.

The study and analysis of phraseological units of a foreign language is an interesting, but, at the same time, difficult task. In many cases literal translation of PU is impossible because of presence in the meaning of the PU national-cultural component specific for the native speakers of the given language. Understanding and translation of such PU is possible only under the condition of acquaintance with culture, literature, and customs of a certain nation.

If to analyze the phraseological nominations of age according to this criterion, it is possible to find the evident proof of the described phenomenon. For example, let us take phraseological unit Indian summerthe second youth. Except for this meaning, PU indicates the period of early autumn also. PU Indian summer is of American origin by which a component 'Indian' is explained. In Ukrainian 'grandma's summer' will 
come as its equivalent. For a plenty of similar phraseological units only descriptive translation is possible because of lack of Ukrainian equivalents. Idiom May and December (January) can be an example - young wife and old husband. Another problematic situation may arise when in the meaning of lexemes realias specific for a certain culture are included. In this case additional explanation should be added in order to fully understand a meaning of a lexical unit. For instance, Venture Scout - a member of the Venture School, part of the British Scout Association for boys and girls who are 16 to 20 years old, ranger guide - a girl who belongs to a part of the Guide Association in Britain, for girls between the ages of 14 and 19.

Connection of phraseology with history, culture, traditions and literature of the native speakers of a certain language is most vividly traced in those phraseological units in which one of the components is a proper name. Most phraseological expressions of this type are related to the facts of old days, the proper name (and a phraseological unit as a whole) lost their motivation and can be explained by the etymologic analysis only. Often the proper name in composition of the phraseological unit becomes a 'potential word', wasted lexically, and quite often the appearance of 'general family' meanings is observed, and that is the proof of abstract character of proper name meaning in the units of this type. E.g. Billy Bunter-gluttonous, thick, blundering teenager, Darby and Joan - old, loving married couple, Blimp (Colonel Blimp) - an old man with old-fashioned political ideas, Jack the Lad - a young man who enjoys drinking alcohol and going out with his male friends and who thinks he is sexually attractive.

The next step of our research is to define the stylistic connotation of the age nominations. It is possible to single out the following subgroups: expressions used in formal style: infant - a baby or very young child, peeryour peers are the same age as you, or have the same type of job, social class etc., nubile - a woman who is nubile is young and sexually attractive; expressions used in literary style: sage - an old man who is very wise, maiden - a young girl or a woman who is not married, decline into vale years - to become old, the afternoon of life - declining years, nymph - a beautiful girl or young woman; expressions used in colloquial style: old biddy - an old woman, especially one who is unpleasant or annoying, dirty old man - an older man who is too sexually interested in younger women, trophy wife - a young beautiful woman who is married to a rich successful man who is much older than her; old-fashioned expressions: hag - an ugly or unpleasant woman, especially one who is old or looks like a witch, stripling - a boy who is almost a young man, chit - a young woman who behaves badly and does not respect older people; humorous expressions: yoof-young people, considered as a group, 65/82/97 etc years young - the age of an old person who seems or feels much younger; offensive expressions: old codger - an offensive word for an old man, wrinkly(lies) - 
an offensive word for someone who is old; dialecticisms: old coot $(A E)$ - an old man who you think is strange or unpleasant, old timer $(A E)$ - an old man, senior $(A E)$ - a student in their last year of high school or university, snowbird (AE) - an old person, who every year leaves their home in a cold part of the US to go and live in a warm part of the country for the winter, colleen (Ireland) - a girl or young woman, lass (Scotland) - a girl or young woman, sheila (Australian) - a young woman.

Having analyzed the lexical means of concept AGE verbalization we found out that there are several conceptual bases for the formation of this concept in the language.

First, we can say that the concept consists of four sub-concepts: CHILHOOD, YOUTH, MIDDLE AGE and OLD AGE.

Old-aged people are characterized as 1) weak, boring, repellent (crone an ugly or unpleasant old woman, curmudgeon - an old person who is always annoyed or angry, doddery - weak and not able to do a thing easily because of old age, old fart - a stupid and uninteresting older person); 2) wise, impressive, experienced, respected (dowager - a respected and impressive old lady, father figure - an older man who you trust and respect, patriarch - an old man who is respected as the head of a family or tribe, sage - an old man who is very wise); 3 ) active and energetic (sprightly - an old person who is sprightly is still active and full of energy, spry - a spry old person has energy and is active, a green old age - happy, cheerful old age); 4) sexually obsessed (dirty old man - an older man who is too sexually interested in younger women).

Middle-aged people are characterized as mature, sensible (dry behind the ears - adult, experienced person).

Young people are characterized as 1) inexperienced, careless, disrespectful (whippersnapper - a young person who is too confident and does not show enough respect to older people, callow - young and without experience, chit - a young woman who behaves badly and does not respect older people); 2) rude, violent, alcohol obsessed (Jack the Lad - a young man who enjoys drinking alcohol and going out with his male friends and who thinks he is sexually attractive, ladette - a young woman who likes to do some things that young men typically do, such as drinking a lot of alcohol and talking about sex, lager lout - a young man who drinks too much and behaves violently or rudely, yob(bo) - a rude, noisy, and sometimes violent young man); 3) skilled, successful, sound (an old head on young shoulders a young person who seems to think and behave like an older person, whizzkid - a young person who is very skilled or successful at something, wunderkind - a young person who is very successful); 4) fashionable, beautiful, sexually attractive (Adonis - an extremely attractive young man, Apollo - a very beautiful young man, doll - a word meaning an attractive 
young woman, dolly bird - a pretty young woman, especially one who wears fashionable cloth).

Children are characterized as 1) pretty, obedient (cherub - a young pretty child who behaves very well); 2) disobedient, troublesome (brat - a badly behaved child, little devil-used to talk about a child who behaves badly, but who you like, juvenile delinquent - a child or young person who behaves in a criminal way, ragamuffin - a dirty young child wearing torn clothes, tinker - a disobedient or annoying child).

Thus, having conducted the lexico-semantic analysis of concept AGE verbalization means, we found out that this concept is objectivized with the help of lexical and phraseological units which can be divided into several semantic subgroups.

Analysis of the lexical means of concept AGE representation allows us to draw a conclusion that this concept has a multi-component and multi-layer structure. That is why we may describe the concept in terms of nucleus and periphery using the field model. The nucleus includes the lexemes with high frequency of usage, with the most general, direct meaning, stylistically neutral, without emotional-expressive connotation. In the nucleus the center is selected. The frequency of lexemes in the center of the nucleus far exceeds the frequency of other units.

The lexemes belonging to the close periphery compared with the nucleus are characterized by less frequency, stylistic neutrality, no limitations in usage, and minimum dependence on the context. Distant periphery is made up of linguistic units with low frequency of usage, having stylistic and emotional-expressive limitations. To the extreme periphery belong oldfashioned words, archaisms, and units with vivid stylistic and emotionalexpressive semes.

It can be represented in the following way:

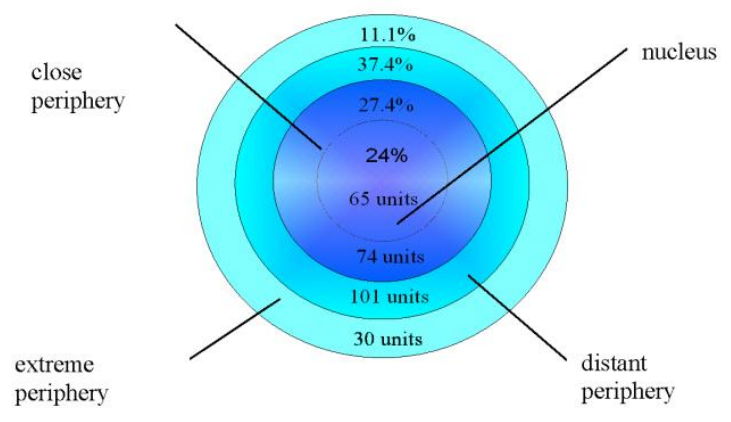

Pic. 1. Lexico-semantic field of concept AGE realization 
Examples of the nucleus lexemes: childhood, child, adulthood, adult, grown-up, middle age, middle-aged, old age, old-aged, aged 5/25 etc., at the age 5/18 etc., baby, grow/grew old, teenager, young .

Examples of the close periphery lexemes: underage, senior citizen, peer group, over-age, coming of age, advanced age/years, wear well, in the flower of life, at one's time of life.

Examples of the distant periphery lexemes: a little man, a young shaver, be of age, long in the tooth, the full age, an old head on young shoulders, chick, dirty old man, father figure, kid sister/brother, stripling .

Examples of the extreme periphery lexemes: wench, tinker, teenybopper, ragamuffin, papoose, minx, nymph, bar mitzvah, flying adder, Billy Bunter.

Thus, concept AGE is realized in the Modern English with the help of lexical and phraseological units, which can be classified according to different parameters organized into a lexico-semantic field.

\section{CONCLUSIONS}

The process of studying the peculiarities of the formation, organization and functioning of the lexical and phraseological semantics helps us understand its nature and substance, extends our knowledge about the semantic language organization, its specific characteristics which enable the language to be a means of cognition and communication. The interrelations of words and consciousness, words and cultural phenomena are reflected in the notion of concept.

The complexity of concept AGE as a social, biological, psychological and cultural phenomenon finds its expression in the language - lexical and phraseological nominations of age. Having analyzed the peculiarities of their semantics we found out that the old age and the young age are mostly often represented in lexis. The separate groups are formed by the words and word combinations which name the process of aging, may be used with any age or reflect seniority relations. All the selected lexemes have been divided into 3 groups according to their gender reference. Here we can observe the predominance of lexemes indicating age regardless of gender which is explained by the universal character of the phenomenon of age as a necessary attribute of any person. Taking into consideration the way of age indication (implicit or explicit) the following figures can be given: $38.4 \%$ of lexical units name age directly and, consequently, $61.6 \%$ - indirectly, with the help of metaphors, euphemisms or other stylistic devices.

Another important issue addressed in our research is the evaluative connotation of the lexical units. Among concept AGE verbalization means $50(18.5 \%)$ units have negative connotation, $34(12.5 \%)$ - positive, and 187 (69\%) are neutral. Units with negative connotation belong mostly to the sub- 
concept OLD AGE. This is a result of ageistic attitudes prevailing in the British culture.

As for the stylistic connotation we can state that among age nominations neutral ones predominate. Among our sampling there are also dialect words, mostly belonging to the American variant of the English language.

Any language reveals the national spirit, mentality, culture of its native speakers. That is why the specific national component is widely presented in the meaning of lexemes. This statement also concerns the age nominations in the English language.

Within the research conducted we have found out that the following characteristics are considered relevant for concept AGE formation: children are treated as obedient, pretty or disobedient, troublesome; youth are regarded to be inexperienced, careless, disrespectful, rude, violent, alcohol obsessed, skilled, successful, sound, fashionable, beautiful, sexually attractive; the only middle-aged people's traits which are reflected in the language are maturity and sensibility. The elderly are stereotyped as weak, boring, repellent, wise, impressive, experienced, respected, active and energetic, sexually obsessed.

Semantic, stylistic, referential analysis of the lexical and phraseological concept verbalization means enables us to build up concept AGE lexicosemantic field and describe its realization in terms of nucleus and periphery.

Further researches in this area can be directed to a more detailed analysis of etymology, structural types of the lexical nominations of age, their functioning in the discourse. One more possible tendency is to investigate how English people as sociate certain words with speakers of different age.

\section{SUMMARY}

The article deals with the analysis of concept AGE and means of its verbalization in the English language. The concept has been treated as a composite mental formation with evaluative, imaginative and notional constituencies. Age, being a complex biological, social and cultural phenomenon, is proved to be expressively realized with the help of lexical and phraseological units. The research has been conducted on the grounds of the sampling including 277 lexemes. The linguistic nominations of concept AGE have been analyzed according to the following criteria: period of life they name; gender reference; explicit or implicit age nomination; evaluative connotation; national cultural elements; stylistic connotation; features of character associated with a particular age. It has been determined that concept AGE consists of four main sub-concepts CHILHOOD, YOUTH, MIDDLE AGE and OLD AGE, which is reflected in its lexical verbalization means. Multidimensional character of the concept allowed us to present its 
field model and analyze lexical and phraseological nominations of age in terms of nucleus and periphery.

\section{REFERENCES}

1. Болдырев Н.Н. Когнитивная семантика: Курс лекций по английской филологии. Тамбов : ТГУ, 2001. $123 \mathrm{c.}$

2. Попова 3.Д., Стернин И.А. Очерки по когнитивной лингвистике. Воронеж : Истоки, 2001. 191 с.

3. Вежбицкая А. Язык. Культура. Познание. Москва : Русские словари, 1997. 416 с.

4. Слышкин Г.Г. От текста к символу. Лингвистические концепты прецедентных текстов в слушании или дискурсе. Москва: Academia, 2000. 128 c.

5. Shakespeare W. The Seven Ages of Man («All the World's a Stage»). URL: https://genius.com/William-shakespeare-the-seven-ages-of-man-allthe-worlds-a-stage-annotated

\section{Information about the authors: Os ova O. O.,}

Candidate of Pedagogical Sciences, Associate Professor, Associate Professor of the Department of Foreign Philology Municipal Establishment "Kharkiv Humanitarian-Pedagogical Academy" of the Kharkiv Regional Council 7, Rustaveli Lane, Kharkiv, 61050, Ukraine

Panchenko V. V., Candidate of Pedagogical Sciences, Lecturer of the Department of Foreign Philology Municipal Establishment "Kharkiv Humanitarian-Pedagogical Academy" of the Kharkiv Regional Council 7, Rustaveli Lane, Kharkiv, 61050, Ukraine 